\title{
THE MEANING OF AL-QALB AND DISCLOSURE IN AL-QUR'AN
}

\author{
Agustiar \\ Fakultas Ushuluddin UIN Suska Riau \\ agustiar_abbas@yahoo.com
}

\begin{abstract}
Human being equipped by God Almighty with a variety of gifts which enable them to carry a burden of duties. The gifts are power of the body, vitality and power al-qalb. Islam has made clear necessity of a proper functioning of al-qalb to think in order to develop knowledge. It will help people to carry caliphate duties on earth properly, under the guidance of al-Qur'an and al-Sunnah. One way to enhance thinking of al-qalb required by Islam is dzikir, therefore, someone will find peace of mind and feel close to God. Feeling close to God, a person's soul will be controlled. Conversely, if a person is not functioning qalb for dzikir, so he will experience drought soul. In al-Qur'an, al-qalb may have some meanings; it refers to the context of verse that contains in it. Moreover, to present the meaning of al-qalb is not always disclosure with the word of al-qalb, but also often disclosure by using the word of al-fuad, al-lub, al-nafs and al-sadr.
\end{abstract}

Keywords: Meaning, Heart, Statement

\section{Introduction}

Relating to the Caliphate responsibility, human beings equipped by God with a variety of gifts enable them to carry the burden of duties. The gifts are power of the body, vitality and power alqalb. ${ }^{1}$ Islam has made clear necessity of a proper functioning of al-qalb to think in order to develop knowledge, it will help people to carry caliphate duties on earth properly, under the guidance of alQur'an and al-Sunnah. Islam also made clear the necessity to use al-qalb to feel and live, in order to improve the quality of one's self, as the Allah say:

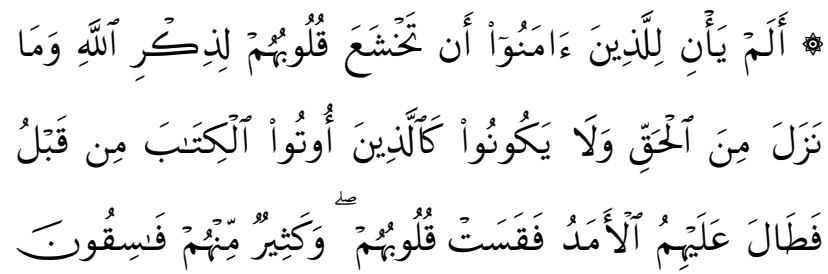

${ }^{1}$ M. Quraish Shihab, Membumikan al-Qur'an (Bandung: Mizan, 1993), 282-284.
The Translation: "Has the time not come for those who have believed that their hearts should become humbly submissive at the remembrance of Allah and what has come down of the truth? And let them not be like those who were given the Scripture before, and a long period passed over them, so their hearts hardened; and many of them are defiantly disobedient" (QS. al-Hadiid: 16).

This verse confirms how important to use the power of al-qalb to feel and appreciate something. One way to enhance thinking of alqalb required by Islam is dzikir. Through dzikir, someone will find peace of mind and feel close to God. Feeling close to God, a person's soul will be controlled. Conversely, if a person is not functioning qalb for dzikir, so he will experience drought soul, as God say: 


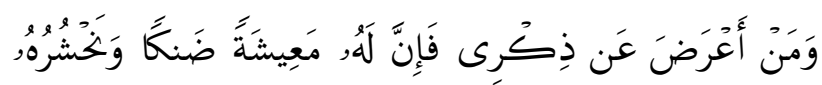

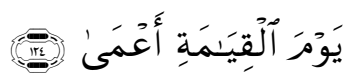

The translation: "And whoever turns away from My remembrance - indeed, he will have a depressed life, and We will gather him on the Day of Resurrection blind" (QS. Taha: 124).

Knowing the nature of al-qalb is very important in Islam, and used it as well as possible is the right way to find the truth and goodness.

Seeing the importance of presence and position of al-qalb for human being, Al-Qur'an is very concerned about and much to talk about. Therefore, this article seeks to reveal the meaning of al-qalb and forms of disclosure in al-Qur 'an.

\section{Understanding of al-Qalb}

The word of al-qalb formed from the root word of qalaba (past tense verb) the meaning is return, it is caused often flick through, once happy and difficult, once agreed and once refused. $\mathrm{Al}$ qalb is potentially very inconsistent. ${ }^{2}$

Etymologically, al-qalb is a lump of oval flesh located in the left chest cavity, it is the center of the blood circulation in the human body. It is called alqalb because it is changing (flick through). ${ }^{3}$ In excerpts of poetry written by Ibnu Mandzur said: "It was not named qalb except because it is changing". ${ }^{4}$

According to Ali Husain Ibn Faris the word of al-qalb has meaning Khalish syai' wa syarafuhu (the core of everything and the most important). It is called qalb al-insan, because it akhlash syai 'fihi wa arfa' uhu (it is a very core in human beings and the most glorious). ${ }^{5}$

${ }^{2}$ M. Quraish Shihab, Wawasan al-Qur'an, Cet. II (Bandung: Mizan, 1996), 288.

${ }^{3}$ Luis Ma'luf, al-Munjid fi al-Lughoh (Beirut: Dar al-Fikr, t.th), 648 .

${ }^{4}$ Ibnu Mandzur Jamal al-Din al-Anshari, Lisan al- 'Arab, Juz I (t.tp: al Muassasah al-Mishriyah, t.th), 181.

${ }^{5}$ Abi Husein Ahmad ibnu Faris, Mu'jam Muqayis alLughoh, Juz. V (Beirut: Dar al-Fikr, t.th), 17.
In term, al-Ghazali defines in his book 'Ihya' 'ulum al-Din' by saying

لطيف ربانية وروحانية لها بالقلب الجسماني تعلق وتلك اللطيفة هي حقيقة الإنسان وهو المدرك العالم العارف من

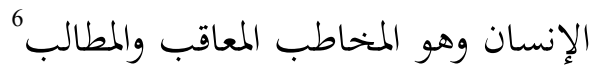

Meant: The gift of God is concealed and spiritual related to heart (qalb) physical. And the gift is the essence of human beings. It had the power to know, understand and grasp something, It gets the order, received sanctions, gets blamed and gets the demands of responsibility.

Definition from al-Ghazali above described two aspects. Physical aspect is hearts as organs in the chest cavity. Spiritual aspect is feeling, understanding and thinking. Only, in this case al-Ghazali focuses on the spiritual aspect that is all the power and strength of al-qalb.

Al-Qur'an when talking about al-qalb, not only focused on the meaning and significance, but many other aspects have looked. These aspects include the nature of al-qalb, position and function of al-qalb in human beings and efforts to nourish al-qalb. In addition, disclosures that convey the same word of al-qalb not always with the word of al-qalb, but sometimes also in other words, like al-Fuad, al-lub, al-nafs, and al-sadr.

\section{Disclosure of al-Qalb in al-Qur'an}

The word comes from the root word of qalaba as described before, in al-Qur'an contained 168 times, 36 times in verb and 132 times noun. From the amount can be detailed, 53 are in surah Makiyyah and 115 are in surah Madaniyyah. ${ }^{7}$

Beside the term of al-qalb contained in alQur'an, there are also others terms to convey the

'6al-Ghazali, Ihya' 'Ulum al-Din, Juz III (t.tp: Dar Ihya' alKutub al-'Arabiyah, t.th), 4.

${ }^{7}$ See Fuad Abd. al-Baqi, al-Mu'jam al-Mufahras li Alfadh al-Qur'an al-Karim (Beirut: Dar al-Fikr, 1981), 549-551. 
same qalb, they are:

\section{Al-Fuad}

Term al-Fuad formed from the root word of faada, it's meant faadahumma wa syiddat alhararat (Heat illness and heat so). ${ }^{8}$ Lexically the word of ashabafuada al-da'wa al-khauf (disease and fear to heart), ${ }^{9}$ it's also meant al-qalb (heart) as contained in al-Qur'an Surah al-Qasash:10.

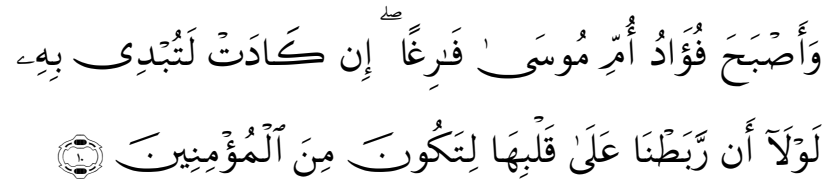

Translation: And the heart of Moses' mother became empty [of all else]. She was about to disclose [the matter concerning] him had We not bound fast her heart that she would be of the believers (QS. al-Qasash:10).

The word of al-fuad and similar with it, in Alquran find 16 times, entirely contained in a surah Makkiyah, with details: 3 times alFuadword, twice fuaduka/fuadaka words, 8 times afidata word, or afidatu word, and 3 times afidatuhum/afidatuhum word. ${ }^{10}$

After collecting and analysis of the data about al-Fuad word in al-Qur'an can be understood that the word is accompanied by alsama' (hearing) and al-bashar (sight) as much as 8 times, which is contained in QS. al-Mu'minun: 78, QS. as-Sajdah: 9, twice in the QS. al-Ahqaf: 26, and QS. al-Mulk; 23.

Based on the description above, it found some information. First, the term al-fuad and partly termof al-qalb are equally embodied in the form of a noun. Second, those term accompanied with al-sama' and al-bashar, each 8 times. Term al-sama 'and al-bashar is a component or tool to understand outward information, then the information is absorbed by the al-qalb or al-Fuad,

\footnotetext{
${ }^{8}$ Abi Husein Ahmad ibnu Faris, 469.

${ }^{9}$ Ibrahim Anis et.al., al-Mu'jam al-Wasith, Juz II (Kairo: t.p, 1972), 671 .

${ }^{10}$ Fuad Abd. al-Baqi, 549-551.
}

to create knowledge. The existence of the word al-sama 'and al-bashar equally accompany the term of al-qalb and al-Fuad indicates an understanding that the word of al-qalb and alfuad are one meaning (al-Fuad is al-qalb).

To prove that the word of al-Fuad synonymous with the word al-qalb, the writer will examine some of the following verses:

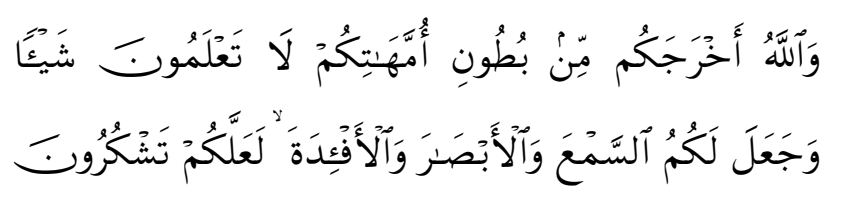

The translation: "And Allah has extracted you from the wombs of your mothers not knowing a thing, and He made for you hearing and vision and intellect that perhaps you would be grateful".

This verse describes the human condition when it was first born into the world. When born, people did not know anything, he did not know which ones are good and which are bad and he has not been able to discern what is useful and what is harmful. Along with the time, God create the ears, eyes, and Fuad (heart) that they bring since born with functioning. Functioning ear to hear, eyes to see and heart function serves to feel and understand something. With the functioning of the ear, eye, and heart, man can understand which benefits and which are harmful to life, and is able to distinguish between what is good and what is bad. From these are expected people really thank to God, to worship him and use these favors in accordance with the purpose of God to give. ${ }^{11}$

In this verse the word al-fuad preceded by the word of al-sama' and al-bashar. This shows how important the presence of al-Fuad (heart) to absorb and understand the information generated by ear and eye. This verse also indicates how

\footnotetext{
${ }^{11}$ Muhammad ibn Ali al-Syaukani, Fath al-Qadir, Juz IV (Beirut: Dar al-Ma'arif, t.th), 306.
} 
important the role of fuad for human beings. Therefore it should be function properly and well, by following the promptings of Satan and impulses lust, so people will fall into the abyss of humiliation and misery.

In QS. al-An'am: 113, Allah say:
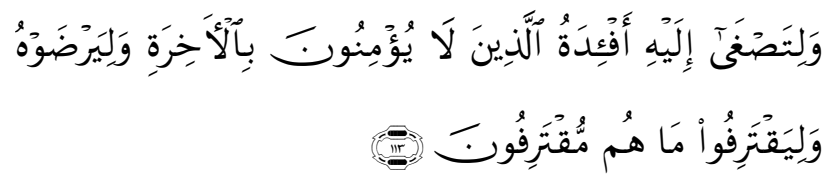

The Translation: "And [it is] so the hearts of those who disbelieve in the Hereafter will incline toward it and that they will be satisfied with it and that they will commit that which they are committing".

This verse is part of the previous verse stating about the devil (of sorts) and human (of sorts) jinn, some of them whispered to the others beautiful words to deceive (mankind). On this verse Allah explains the promptings of the devil is to tempt the majority of people who believe in His Messenger, to abandon their religion, and those who do not believe in the afterlife tend to follow the promptings, because such trends is appropriate with the wishes of lust that always encourage people to have fun and commit adultery. Therefore, they will feel good to him (whisper) and regardless of the consequences will be earned in the future. Finally, they will do what devil do. ${ }^{12}$

From the interpretation above, it can be known that in al-fuad there is a force that greatly affects human behavior, namely lust that always invites people to seek pleasure and do disobedience. If humans tend to follow the desires then he will get the pain of hell in the hereafter.

In another verse Allah says:

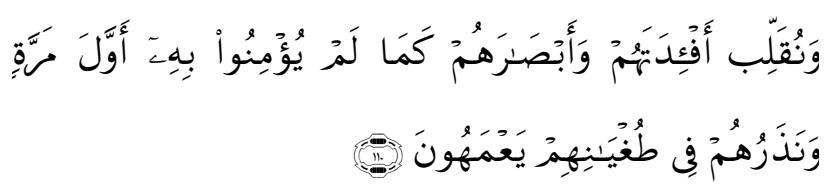

${ }^{12}$ Musthafa al-Maraghi, Tafsir al-Maraghi, Juz VIII (Beirut: Dar al-Fikr, Beirut, t.th), 41.
The Translation: "And We will turn away their hearts and their eyes just as they refused to believe in it the first time. And We will leave them in their transgression, wandering blindly".

This verse shows that faith and infidelity is a provision of God. Kufur people, his heart reversed by God to disbelieve in al-Qur'an, and as if he did not know al-Qur'an before. If there is a verse explains about the existence of Apostle and his message was read, they do not get least to benefit from the verse, because they increasingly run from the truth and choose infidelity. ${ }^{13}$ The word of al-Fuad contained in this verse according to al-Thaba thaba' $i$ is the hearts of kafir who damaged, they will not accept kindness forever, their hearts have been enslaved by lust, therefore they are more distant from the truth and faith. ${ }^{14}$

From the interpretation of the verses contain the word of al-fuad before, came to understanding that the word of al-fuad is similar meaning with al-qalb. But though both have the same meaning, but there are certain differences. The difference is based on the fact that the word of al-fuad that present in al-Qur'an is not found in the form of verb, whereas al-qalb there are revealed in the form of verb. In addition, The word of al-fuad is not found in tandem with the vocabulary that has thinking meaning, while alqalb more encountered in conjunction with the term of thinking, such as al-'aql, al-tadabbur, altafaqquh, etc. This suggests that al-Fuad convey the same meaning with qalb in conscience or feelings, not minds.

\section{Al-Lub}

The term of al-lub formed from the root word of laba has meaning aqama 'ala al-amr

\footnotetext{
${ }^{13}$ Fahruddin al-Razi, al-Tafsir al-Kabir, Juz V (Beirut: Dar al-Kutub al-'ilmiyyah, t.th), 52 .

${ }^{14}$ Muhammad Husein al-Thabathaba'i, al-Mizan fi-Tafsir al-Qur'an, Juz V (Iran: Mathba' Isma'iliyyah, 1412 H), 324.
} 
(Hold on to a case), al-luzum, tsubut wa al-kalis (consistent, consequent and something pure). ${ }^{15}$ For example, the disclosure al-rajullaba bi hadzihi al-amr (this man is consistent in dealing with the problem or disclosure of imra' ah labbat muhibbah lizaujiha means innaha tsabitah 'ala wuddihi abad (women was consistent with affection to the husband forever. ${ }^{16}$

Lexically, the word of al-lub has many meaning namely: al-khalis wa al-khiyyar (something pure and elected), iqamah wa luzum (consistent and consequent), and also means "main". ${ }^{17}$ According to al-Ashfahani, al-lub is al'aql al-khalis min al-sawaib (sense of clear and clean from all defilement). Furthermore, he said wa kullu lubb 'aql walaisa kullu 'aql lub wa la yudrikuha illa al-'uqul al-zakiyyah (each lub is reasonable, but not all of the sense is $l u b$ and will not achieve $l u b$ except pure sense).$^{18}$

From the explanation above, it can be understood that the word $a l-l u b$ has three main meanings, namely tsubut or luzum (consistent or consequent), khalis (clear and pure) and al-'aql al-khalis (clear sense). The first notion implicated for the meaning of the attitude that is always consistent and consequent. The second, understanding implicated for the meaning of the essence. This understanding is significance with the meaning of al-qalb. The third, understanding implicated in the core meaning of sense or thought. To inform truth of this understanding will be clarified by the word of al-lub that find in alQur'an.

The similar word with the term of al-lub is found in al-Qur' an 16 times, 8 words contained in the verses of Makiyah and 8 words found in verses of Madaniyah. Each word contained in QS. al-Baqarah: 179, 197, 269; QS. Ali Imran: 7, 190;

\footnotetext{
${ }^{15}$ Luis Ma'luf, 709.

${ }^{16}$ Abi Husain Ahmad Ibn Faris, 17.

${ }^{17}$ Ibrahim Anis et.al., 753.

${ }^{18}$ Al-Raghib al-Ashfahani, Mu'jam Mufrodat li Alfadh AlQur'an (Beirut: Dar al-Fikr, t.th). 426.
}

QS. al-Maidah: 100; QS. Yusuf: 111; QS. al-Ra'd: 19; QS. Ibrahim: 52; QS. al-Shad: 29.43; QS. alZumr: 9, 18, 21; QS. al-Ghafir: 54; QS. al-Thalaq: $10 .{ }^{19}$

Based on the data above, there are two interesting things to be studied further. First, the entire al-lub expressed in the form of jama' taktsir (irregular plural). Secondly, the terms accompany that word is very diverse, which is not merely connotes a sense. These terms include taqwa 3 times, dzikir 9 times, huda 2 times, tadabbur once and the word 'ibrah once. ${ }^{20}$

With the unfolding of the word al-lub in the form jama'taktsir, there are two elements can be interpreted. First; changed from its original form and the change will not have a clear form or patron. Second: changed from its original only on harakah (punctuation) and letters, do not change the meaning. This means on the one hand, it has a change or dynamic, on the other hand, it remains consistent in its characteristics. On such conditions, if it is associated with the notion of the word $a l-l u b$, can be known of the equation, which is equally consistent, while the element of dynamic got from the word is diversity of terms that accompany the word of al-lub, which not only has a sense of reasonable thought. These terms are: dzikir mean a la wa al-syaraf (high and noble). ${ }^{21}$ Huda mean al-taqaddum li irsyad (go head to give instructions). Lexically, it also means istarsyada (ask for directions) or dalalah bi lutf (giving instructions in soft). ${ }^{22}$ while the word alTaqwa means daf'u syai'an syai' bi ghairihi (to prevent something from something else) ${ }^{23}$

Departing from partial terms accompanied $a l-l u b$ word can be understood that ulu al-albab is a person who has a complete knowledge, intellectual capacity, personal integrity, creative

\footnotetext{
${ }^{19}$ Fuad Abd. Al-Baqi, 644.

${ }^{20}$ Ibid.

${ }^{21}$ Abi Husain Ibn Faris, 358.

${ }^{22}$ Al-Raghib al-Ashfahani, 181.

${ }^{23}$ Ibid., 131.
} 
and dynamic. Someone had called ulu al-bab when he has an element of thought, remembering Lord, devoted, always giving instructions, dynamic and always consistently make efforts in development. Thus, the word of al-lub is more integral and more essential than the word of alqalb. Al-lub means something present in human being, while ulu al-bab means people who gained enlightenment which is able to do thinking integration efforts and constantly dzikir are on the way of Allah. One verse contains the word $a l-l u b$ is QS. Shad: 29:

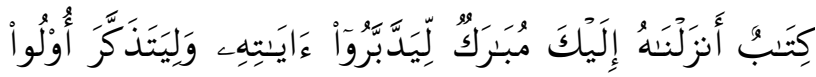

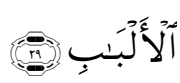

The Translation: "[This is] a blessed Book which We have revealed to you, [O Muhammad], that they might reflect upon its verses and that those of understanding would be reminded".

Most of interpreter scholars interpret ulu $a l-b a b$ with the meaning ulu al-'uqul (Those who have a sense). ${ }^{24}$ According to interpretation of these scholars, attempts to verification of disclosure ulu al-bab do not always indicate the sense of thinking. Based on the analysis of the vocabulary ulu al-bab can be understood that the word is not only accompanied by thinking term, but it accompanied by the term of huda, dzikir, taqwa and ibrah. Furthermore term aql only revealed in the form of the verb. As contained in QS. al-Hajj: 46: wa lahum qulub ya'qiluna biha. Term mind in this verse (in the form of a verb) means the activity of thought that comes from the heart, because the $a l-l u b$ integrated all mental activity is clear and pure, so it is heart quality or al-qalb quality.

\section{Al-Nafs}

The term of al-nafs is formed from the root word of nafasa which means ashaba bi ain

\footnotetext{
${ }^{24} \mathrm{Abu}$ Bakar al-Jazari, Aisar al-Tafsir li Kalam al'Ali alKabir, Juz IV (t.tp: al-Ikhraj al-Faniy, 1987), 12.
}

(Overwrite the one or a person). ${ }^{25}$ Al-nafs means al-Ruh (spirit), for example kharajat nafsuhu (his spirit has come out). It also means that al-dam (blood), as pharase dafaqa nafsuhu (the blood gushing). It also could mean dzat syai'wa 'ainuhu (Essence something and herself) as a disclosure jaa nafsuhu (come from itself). In other contexts it's also meant al-qashd wa al-iradah (one goal and will), such as fi nafsi disclosure 'an af' ala $k a d z a$ (my goal is to do so). ${ }^{26}$

Lexically al-nafs means mauqi' al-qalb wa al-dhamir yakunu fihi al-sirru al-khafi (the central of feeling and desire, in which there is a hidden secret). Sometimes it means' indi (what is in themselves), such as the sentence ana a'lamu bima fi nafsika (I know what is in you). In other contexts it also means ma yuwajjih al-insan 'ala af'al min khair wa syarr (something that encourages people to do deeds, good or bad commendable). As a disclosure of amaratni nafsi (my soul told me so). ${ }^{27}$

The terminology, as said by al-Qushayri in the book of al-Risala, that al-nafs is something causes human behavior reprehensible and damnable. ${ }^{28}$

According to al-Ghazali, the word of alnafs has two meanings. First, it is a sense of anger and lust to commit reprehensible acts. Secondly, it is a subtle feeling which is the human spirit and the essence of him. According to al-Ghazali, the second meaning has two dimensions. When it was under the control of the power of reason and the light of faith, it called al-nafs al-muthmain (quiet soul), and if tranquility is not perfect and open conflict with lust, it called al-nafs allawwamah (soul blamed himself). ${ }^{29}$ In al-Qur'an,

\footnotetext{
${ }^{25}$ Luis Ma'luf, 826.

${ }^{26}$ Muhammad ibn Abi Bakr ibn 'Abd. Al-Qadir al-Razi, Mukhtar al-Shihhah (Beirut: Dar al-Fikr, 1981).

${ }^{27}$ Majma' al-Lughoh, Mu'jam alfadh al-Qur'an al-Karim, Juz II, Cet. II (t.tp: al-Haiah al-Mishriyah, 1970), 741.

${ }^{28}$ Abi Qasim al-Qusyairi, al-Risalah al-Qusyairiyah $f i$ 'ilm al- Tasawwuf (t.tp: Dar al-Khair, t.th), 87.

${ }^{29}$ al-Ghazali, 4.
} 
al-nafs find as many as 259 times, which is scattered in some verses, with details mufrad nafs as many as 140 times, in form jama' anfus as much as 153 times and jama' nufus twice. ${ }^{30}$

The term of al-nafs, in Al-qur'an also has many of meanings. It meant dzat al-insan wa haqiqatuhu (the nature of human being). As we find in QS. al-Baqarah: 48, 233 and others. It also means that al-jins (type). As listed in QS. alTaubah: 128, QS. al-Nahl: 72, etc. It also means $d z a t$ of God (Essence of God and himself). As stated in al-Qur'an surah Ali Imran: 28 and QS. al-Maidah: 116. In another context, it also means dzat al-insan al-muayyanah (a specific self), such as Adam, as it is find in Surah al-An'am 98, QS. Al-A'raf: 189, etc. It may be also meant al-Ruh (soul) as is found in QS. al-Zumr: 42, QS. alTaubah: 55, etc. ${ }^{31}$ According to M. Quraish Shihab, the word of al-nafs may be meant something in human being which create behavior. ${ }^{32}$ As contained in QS. al-Ra'd: 11. We find the word of al-nafs also meant ma yad'u ala al-insan al-khairi wa alsharr (the power to lead person to do good deed and despicable). It is found in QS.Yusuf: 18, QS. al-Qiyamah: 2 etc. The important meaning is alqalb wa al-dhamir (hearts and feeling). ${ }^{33} \mathrm{As}$ it is found in QS. al-Maidah: 84, QS. al-A'raf: 205 etc.

From the data above it can be seen that the meaning of al-nafs in al-Qur'an broader and more diverse than the meaning intended by linguists. Moreover, in this discussion, both of the meaning last are the meaning related with alqalb. First, a potential encourage people to do good or bad (as stated in al-Qur'an, al-Maidah: 30), and second, it means heart and feelings or the will (as mentioned in al-Qur'an surah Ali Imran: 154). Thus, nafs is the power lead qalb tend to follow nafs. ${ }^{34}$ If qalb tend to bad, it will

\footnotetext{
${ }^{30}$ Fuad Abd al-Baqi, 285.

${ }^{31}$ Majma' al-Lughah, 746.

${ }^{32}$ M. Quraish Shihab, Wawasan al-Qur'an..., 282.

${ }^{33}$ Fuad Abd. al-Baqi, 285.

${ }^{34}$ M. Quraish Shihab, Wawasan Al-Qur'an..., 289.
}

manipulate human physical to do evil deeds and disgraceful. If qalb tend to do good deed (taqwa), so that it becomes clean and quiet, qalb will manipulate human physical strength to do good deeds and praise, nafs and qalb be calm and peaceful. This is appropriate with QS. al-Ra'd: 28:

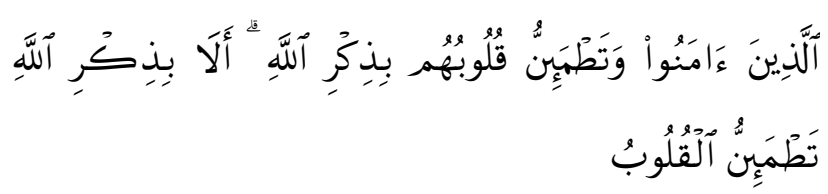

The translation: "Those who have believed and whose hearts are assured by the remembrance of Allah. Unquestionably, by the remembrance of Allah hearts are assured"' (QS. al-Ra'd: 28).

\section{Al-Sadr}

The term of al-Sadr formed from a root word of shadara meant al-ruju' (back). ${ }^{35}$ The word of al-sadr (noun) meant a'la wamuqoddam (something tall and fronted), also means muqaddamu kulli syai' wa awwaluhu (Predecessor and starting of everything). On the other, it's meant shadr al-insan al-ja li al-jariah (chest as part of body), in which there is al-qalb. ${ }^{36}$

The word of al-sadr (noun) in al-Qur'an may be meant al-sadr al-jarihah (chest as limbs). ${ }^{37}$ It may know from the arrangement of words and letters, such as $f i$ (preposition) a disclosure of ta'ma al-qulub allatifi al-shudur (The blind is the hearts in the chest). It may be isyarah ila al-'aql wa alilmi wa isyarah ila al-Sa'adah (sign on mind, knowledge and happiness). In another hand, it may be also meant isyarah ila sair al-quwa min alsyahwat al-hawa wa al ghadlab (signal on lust, passion and anger on human heart). ${ }^{38}$

The word of al-sadr which implies a happiness and tolerance can be found in QS. alInsyirah verse 1-2:

\footnotetext{
${ }^{35}$ Majma' al-Lughah, 62.

${ }^{36} \mathrm{Ibn}$ Mandzur, Lisan al-Lisan, Cet.I (Beirut: Dar alKutubal-Ilmiyah, 1993), 11.

${ }^{37}$ Majma' al-Lughah, 61 .

${ }^{38}$ Al-Raghib al-Ashfahani, 284.
} 


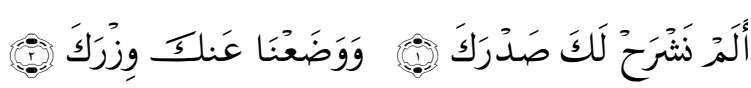

The Translation: "Have we not expanded for you your breast? (1); And we removed from you your burden (2)".

The term of al shadr in this verse is preceded by an disclosure of alam nasyrah (in questions) which means: Have we not expanded for you your breast? The questions submitted by Allah in this verse are not intended for a question that requires an answer, but the question disclosure aims to strengthen the presence of an event, ie nasyrah laka shadrak (we expanded for you your breast). ${ }^{39}$ So, the clause referred to qad syarrahna shadrak (Indeed we expanded your breast). Expended in this verse is the Messenger's heart.

This verse affirms that God expanded the heart of Muhammad, with the disclosure: indeed we expended of your heart Muhammad and we also remove from you hesitate and doleful, as a result of hatred and hostility shown your enemies to you. ${ }^{40}$ In this verse Allah focus on the word of al-Sadr which got expanded, this is because heart is the central of feeling and understanding. ${ }^{41}$

From the above explanation, it can be argued that the word of al-sadr literally means part of the human body. In al-Qur'an, this term may be used not in true meaning (essential), but it refers to the heart reside in the chest. It can be found in verses which arrangement of the word $a l-s a d r$ as fa'il (subject) or as maf'ul (object), such as the disclosure of yasrah shadrahu, tukhfi shudur, etc. such as hashirat shudurukum, etc. This disclosures repeated in al-Qur'an as many as 16. Eight times as $f a^{\prime} i l$ and eight times as maf'ul. On the other hand, al-Qur'an displays the word of $a l$-sadr with a real meaning (essential). It can be found in verses the arrangement of puts

\footnotetext{
${ }^{39}$ Muhammad al-Syaukani, Juz V, 461.

${ }^{40}$ Mushthafa al-Maraghi, Juz X, 189.

${ }^{41}$ Muhammad al-Syaukani.
}

the word al-sadr after preposition of jar or put the word of al-sadr as mudhaf ilaihi (noun). As disclosures fi shudur and dzat al-shudur. This disclosures repeat 28 times in al-Qur'an, with 16 times after preposition (fi) and 12 times after mudhaf 'ilaih (after the word dzat). ${ }^{42}$

In addition, al-Qur'an based on Arabic structure always use part of something to show whole other. Such as the word of "bow down" in praying mean standing, bowing and others. AlQur'an also used tone to describe all, but that is only one part, such as his word which means "They put their fingers into their ears." (Qur'an, al-Baqarah: 19) the meaning is fingertips. AlQur'an also used to call place something, but what is meant by it content, such as the disclosure "Ask the village" (QS. Yusuf: 82), which is intended occupants. ${ }^{43}$

Related to the last statement, the meaning of al-sadr is chest as a qalb (herat). As Allah says in Surah al-Hajj: 46:

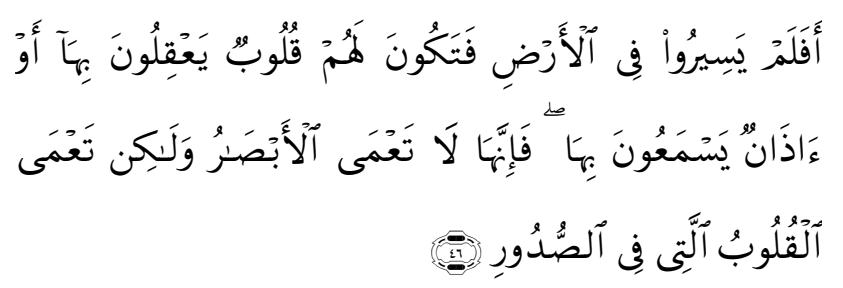

The translation: "Have they not traveled through the land? Have they no hearts to learn wisdom, or ears to hear the Truth? Certainly it is not their eyes which are blind, but it is the hearts in their breasts which are blind".

\section{Conclusion}

From the explanation above it can be concluded and generally understood that the word of al-qalb, al-Fuad, al-lub, al-nafs, and al-sadr mean heart. But specifically, each of these terms has different meanings. Al-qalb means the heart which tends to inconsistent and constantly changing, al-Fuad is conscience or delicate

\footnotetext{
${ }^{42}$ Fuad Abd. Baqi, 404.

${ }^{43}$ M. Quraish Shihab, Wawasan al-Qur'an..., 290-291.
} 
feelings that tend to be fixed and consistently good instead of the mind, $a l-l u b$ is a mind that is clear, clean of any dirt, al-nafs is more potential to encourage people to do good deed and devil deed , and $a l-s a d r$ is a heart reside in chest refer to happiness and spaciousness chest. The fifth terms have the same meaning bond, also different meaning functionally.

\section{Bibliography}

al-Ashfahani, al-Raghib. Mu'jam Mufrodat li Alfadh Al-Qur'an. Beirut: Dar al-Fikr, t.th.

al-Baqi, Fuad Abd. al-Mu'jam al-Mufahras li Alfadh al-Qur'an al-Karim. Beirut: Dar al-Fikr, 1981.

al-Ghazali. Ihya' 'Ulum al-Din. Juz III. t.tp: Dar Ihya' al-Kutub al-'Arabiyah, t.th.

al-Jazari, Abu Bakar. Aisar al-Tafsir li Kalam al'Ali al-Kabir. Juz IV. t.tp: al-Ikhraj alFaniy, 1987.

al-Maraghi, Musthafa. Tafsir al-Maraghi. Juz VIII dan X. Beirut: Dar al-Fikr, Beirut, t.th.

al-Qusyairi, Abi Qasim. al-Risalah alQusyairiyah fi 'ilm al-Tasawwuf.t.tp: Dar al-Khair, t.th.
al-Razi, Fahruddin. al-Tafsir al-Kabir. Juz V. Beirut: Dar al-Kutub al-'ilmiyyah, t.th.

al-Razi, Muhammad ibn Abi Bakr ibn 'Abd. AlQadir. Mukhtar al-Shihhah. Beirut: Dar alFikr, 1981.

al-Syaukani, Muhammad ibn Ali. Fath al-Qadir. Juz IV dan V. Beirut: Dar al-Ma'arif, t.th.

al-Thabathaba'i, Muhammad Husein. al-Mizan fiTafsir al-Qur'an. Juz V. Iran: Mathba' Isma'iliyyah, $1412 \mathrm{H}$.

Anis, Ibrahim et.al. al-Mu'jam al-Wasith. Juz II. Kairo: t.p, 1972.

Ibnu Faris, Abi Husein Ahmad. Mu'jam Muqayis al-Lughoh. Juz. V. Beirut: Dar al-Fikr, t.th.

Ibn Mandzur. Lisan al-Lisan. Cet.I. Beirut: Dar al-Kutubal-Ilmiyah, 1993.

M. Quraish Shihab. Membumikan al-Qur'an. Bandung: Mizan, 1993.

M. Quraish Shihab. Wawasan al-Qur'an. Cet. II. Bandung: Mizan, 1996.

Ma'luf, Luis. al-Munjid fi al-Lughoh. Beirut: Dar al-Fikr, t.th

Majma' al-Lughoh. Mu'jam alfadh al-Qur'an alKarim. Juz II. Cet. II. t.tp: al-Haiah alMishriyah, 1970. 